\title{
SPECIFICITY AND SENSITIVITY OF THE NEW TEST FOR SEROLOGICAL EVALUATION OF TUBERCULOSIS USING MPT83-MPT63 FUSION ANTIGEN
}

\author{
A. A. SIROMOLOT $T^{1,2 凶}$, T. O. CHUDINA', I. S. DANILOVA \\ O. M. REKALOVA , D. V. KOLYBO ${ }^{1,2}$, S. V. KOMISARENKO \\ ${ }^{1}$ ESC Institute of Biology and Medicine, Taras Shevchenko National University of Kyiv, Ukraine; \\ ${ }^{2}$ Palladin Institute of Biochemistry, National Academy of Sciences of Ukraine, Kyiv; \\ ${ }^{3}$ NSC Institute of Experimental and Clinical Veterinary Medicine, Kharkiv, Ukraine; \\ ${ }^{4}$ SI National Institute of Phthisiology and Pulmonology \\ named after F. G. Yanovsky National Academy \\ of Medical Sciences of Ukraine, Kyiv; \\ 凶e-mail:saa0205@ukr.net
}

The aim of this work was to characterize the experimental test-system based on MPT83-MPT63 fusion antigen with reference commercial diagnostics and investigate the basic characteristics of enzyme-linked immunosorbent assay (ELISA) tests such as specificity and sensitivity. In addition, we investigated the correlation of biochemical and immunological parameters of blood samples of patients with tuberculosis, which was correctly diagnosed by those test-systems. It was shown that the developed test-system match the existing ones regarding the criteria of reliability and the basic requirements of ELISA kits. Recommendations for the testing of serum samples and indications for the use of the proposed serological diagnostic methods has been suggested.

Ke y w ord s: diagnostic of tuberculosis, recombinant protein, ELISA.

$\mathrm{T}$ uberculosis (TB), caused by Mycobacterium tuberculosis, is still the major cause of death and suffering among infectious diseases worldwide. Our knowledge of the prevalence of the early phase of $M$. tuberculosis infection in humans is very limited, moreover multidrug-resistant strains continue to spread with an estimated 490000 new cases in 2016 [1]. In this way, the search for a new diagnostics and methodical approaches for TB infection detecting in the early stages and for mass application use remains to be actual.

Various M. tuberculosis antigens have been well characterized and have been used in TB detection assays and there is ongoing research on multiple antigen based serological assays [2-4]. The present study measured the antibody response using ELISA test to fusion protein MPT83-MPT63 obtained previously [5]. These two antigens are synthesized in abundance in M. tuberculosis or M. bovis strains [6].
The use of these proteins is advisable because they are absent in the genome of most not pathogenic mycobacteria [6].

The aim of this investigation was compare new developed MPT83-MPT63 ELISA test-system with two existing commercial products based on the same immunological method. Also, we have analyzed correlation between recognition of sera from TB patients employee ELISA with different antigenic substances. Determination of patients TB status with different ELISA test-systems was done with analazing such common and important parameters as red and white blood cells count and biochemical measurement of some metabolic intermediate molecules, proteins and certain enzymes activity in blood sera samples. A comprehensive determination of the level of specific antibodies and biochemical markers will allow to determine the severity of the course of the infectious process in TB patients and correctly

(c) 2018 Siromolot A. A. et al. This is an open-access article distributed under the terms of the Creative Commons Attribution License, which permits unrestricted use, distribution, and reproduction in any medium, provided the original author and source are credited. 
choose the strategy of treatment of the patient and the effectiveness of the therapy.

It is known that the activation of the immune system mediates the inflammation seen in the disease. The haemogram of patients with TB varies during the treatment and type of disease. In the haemogram of patients with infiltrative tuberculosis, there was a greater severity of inflammation events, and in disseminated form - of allergic and autoimmune processes [7, 8]. It exerts a dazzling variety of hematological effects involving both cell and plasma components. Biochemical blood assay can also indicate an active inflammatory process and metabolism disorders of the body caused by infectious agents [9]. The hematological changes sometimes act as useful factors providing a clue to diagnosis, assessing the prognosis, indicating the complication of underlying infection as well as therapy and response to therapy. In parallel, the measurement of antibodies to the pathogen with correlation blood cells counts may help identify correct detection strategies of the disease and the application of serological methods for diagnosis of TB [10].

Worth noting that changes in hematological or biochemical blood constants may affect the sensitivity of the ELISA [11, 12].

Reversible peripheral blood abnormalities such haemotological and biochemical chagnes are commonly associated with different infectious diseases [13-16]. Also, relationship between hematological abnormalities and mycobacterial infection has come from an understanding of the immunology of mycobacterial infection. The atypical and varied spectrum of clinical presentation of TB poses a diagnostic and therapeutic challenge to the physicians $[17,18]$. Moreover, they are often associated with diet, alcohol, drug use, stress, environmental factors, which is a significant therapeutic difficulty in assessing such factors in the course of a particular disease.

\section{Matherial and Methods}

Blood sera. Venous blood sera samples of patients infected with M.tuberculosis ( $n=50$ ), healthy $(n=22)$ and sick on nontuberculous lung diseases ( $n=22$, including chronic obstructive pulmonary disease (COPD), $n=10$; cystic fibrosis, $n=2$; bronchial asthma, $n=4$; chronic bronchitis, $n=2$; pneumonia, $n=2$; abscess, $n=1$; lymphadenopathy, $n=1$ ) were used in the study. Patients were not characterized by the presence of any of the concomitant diseases (e.g. diabetes mellitus, hepatitis,
AIDS, autoimmune diseases). Humans sera samples were obtained from healthy donors and TB infected men and women wide age range, received in cooperation with the State Institution National Institute of Phthisiology and Pulmonology named after F. G. Yanovsky National Academy of Medical Sciences of Ukraine. The donors and patients were informed and agreed to use their biological materials for research purposes. Blood sera samples have been used as secondary antibodies for the ELISA test.

The research was conducted in compliance with all bioethical requirements.

Immunoenzymatic kits. Commercial ELISA kits developed for detection of IgG antibodies to M. tuberculosis: test-system\#1 (Ukraine), test-system\#2 (Russia) and new developed MPT83-MPT63 test-system "IB-Chem Anti-Mycobacterium tuberculosis" (Ukraine) were also used.

Indirect ELISA procedure. The use of two reference ELISA kits \#1 and \#2 was carried out in accordance with the manufacturer's instructions. Recombinant MPT83-MPT63 adsorption was performed in $0.05 \mathrm{M}$ carbonate-bicarbonate buffer solution (pH 9.6) for $10 \mathrm{~min}$ at $4{ }^{\circ} \mathrm{C}$ at concentration $0.5 \mu \mathrm{g} / \mathrm{ml}$. Bovine serum albumin (BSA) was used as 96-well plate free areas blocking agent. Dilution of patient's sera was carried out at $1: 50$. For specific antibodies detection to pathogen, there was used conjugate of monoclonal antibodies to human IgG with horseradish peroxidase (1:3000) incubated at $37{ }^{\circ} \mathrm{C}$ for $30 \mathrm{~min}$. TMB $\left(3,3^{\prime}, 5,5^{\prime}\right.$-tetramethylbenzidine, $0.003 \% \mathrm{H}_{2} \mathrm{O}_{2}, 0.15 \mathrm{M}$ citrate buffered solution, $\mathrm{pH}$ 5.0) was used as chromogen substrate incubated at room temperature for $30 \mathrm{~min}$ in dark. Optical density (OD) was measured at wavelength $490 \mathrm{~nm}$. More detailed information on how to use new developed test-system "IB-Chem Anti-Mycobacterium tuberculosis" based on MPT83-MPT63 fusion antigen is described in the manual.

Statistical data analysis. The data were statistically treated using standard MO Excel and Origin 8.0 software. To compare the dat in two groups we used Student's $t$-criterion test. The difference was considered statistically significant for $P<0.05$.

\section{Results and Discussion}

In this prospective study, efforts were made to evaluate the immunodiagnostic potential of developing a novel ELISA-based serodiagnostic test employing a MPT83-MT63 fusion antigen to enhance the sensitivity of the immunoassay. Also, attempts 
were made to check the specificity of the antigen in comparison with two ELISA kits on the Ukrainian market. Another task was to analyze the general serum biochemistry and haemograms in patients with TB which were identified as a sick with commercial or a developed by us test-system in comparison with the same characteristics of patients which were not identified by any of the ELISA diagnostic tools.

Non-invasive approach to diagnosis of pulmonary TB is urgently needed. ELISA is by far the most common method of diagnosis due to a number of undeniable benefits. One such advantage is accuracy, which is provided by sufficient specificity sufficient specificity and sensitivity is a guarantee of reliable results.

Dozens of commercial serological tests for TB are being marketed in many parts of the world, despite previous systematic reviews having reported variable sensitivity and specificity of these tests $[19,20]$. However, despite this, the shortcomings of the current methods for controlling TB are obsolete and very inaccurate. Also, most trustful methods are very lengthy, or expansive, or require specially educated personnel, which is not always available and not conducive to quickly determine the diagnosis.

An indirect antibody ELISA was performed to detect $M$. tuberculosis (test system \#1 (Ukraine) and \#2 (Russia) or recombinant fusion antigen MPT83MPT63 antibodies in the TB, nontuberculous lung diseases and healthy patients sera. A high level of anti-MPT83-MPT63 antibodies was detected in most cases of TB.

Sensitivity and specificity of the test system calculated by conventional formulas for serological tests based immunoenzyme analysis (IEA):

$$
\text { Specificity }=\mathrm{N} /(\mathrm{N}+\mathrm{FP}) \times 100 \% \text {, }
$$

where $\mathrm{N}-$ number of negative results in healthy, $\mathrm{FP}$ - number of false positive results in healthy.

$$
\text { Sensitivity }=\mathrm{P} /(\mathrm{P}+\mathrm{FN}) \times 100 \% \text {, }
$$

where $\mathrm{P}$ - number of true positive results in patients, $\mathrm{FN}$ - number of false negative results in patients.

Specificity is the ability of the test-system to detect only a certain substance, that is, to identify negative samples without false positive results. The positive result of the analysis of a healthy person serum may be mistakenly interpreted by the physicians as evidence of the presence of a patient's infectious status and may lead to the appointment of a person to cure a disease to which patient does not suffer. Diagnostic sensitivity of the test-system is the ability to detect the maximum possible number of infected patients, that is, to identify positive samples without false negative results.

The testing was conducted in 22 healthy and 22 non-tuberculous lung disease patients. According to the results of the experimental test system based on the recombinant chimeric $M$. tuberculosis protein MPT83-MPT63 the true negative serum test results was in 21 of 22 healthy (95.5\%) and in 21 of 22 nontuberculous lung disease persons (95.5\%). The proportion of true negative serum test results was $95.5 \%$ (the test correctly classifies healthy people). The fraction of false positive results was $4.5 \%$ (Fig. 1).

Thus, the specificity was calculated not only by the results of healthy donors, but also using sera of patients with non-tuberculous lung diseases. The use of an ELISA test-system is appropriate, because the level of specific antibodies (or their absence) is important indicator for distinguished from true TB patients with those who have an another genesis lung pathology.

The proportion of sera with a truly positive result of the analysis $(n=35)$ in relation to all serum of TB patients $(n=50)$ for the experimental test system "IB-Chem Anti-Mycobacterium tuberculosis" was almost 70\% (Fig. 2).

Commercial test systems \#1 (Ukraine) and \#2 (Russia) are also were tested by same characteristics. It was shown (Fig. 2) that both diagnostic kits have the same sensitivity rate at 55\% (compared to $70 \%$ for "IB-Chem Anti-Mycobacterium tuberculosis").

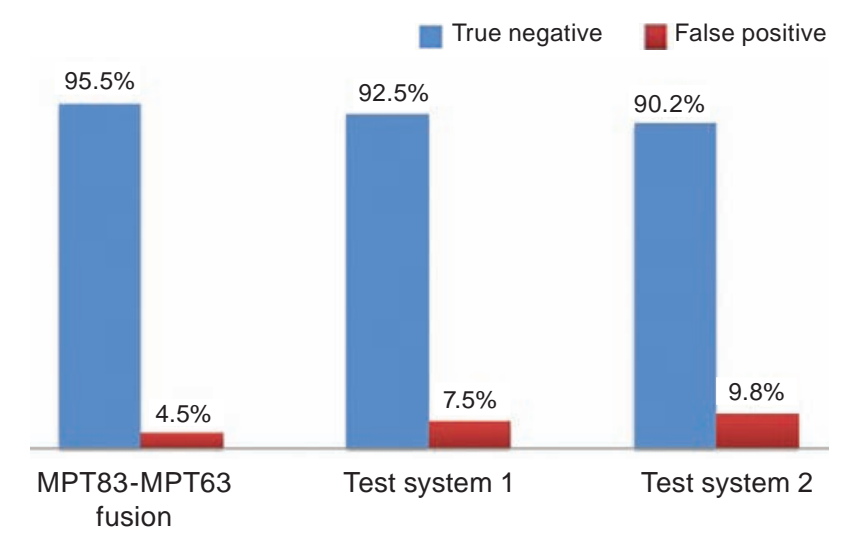

Fig. 1. Specificity of serological test-systems ("IB-Chem Anti-Mycobacterium tuberculosis", \#1 (Ukraine), \#2 (Russia)), \%. All results are statistically confirmed, $P<0,05$ compared to each controls (with test-system \#1 and with test-system \#2). The testing was conducted in 22 healthy and 22 nontuberculous lung disease patients $(n=44)$ 


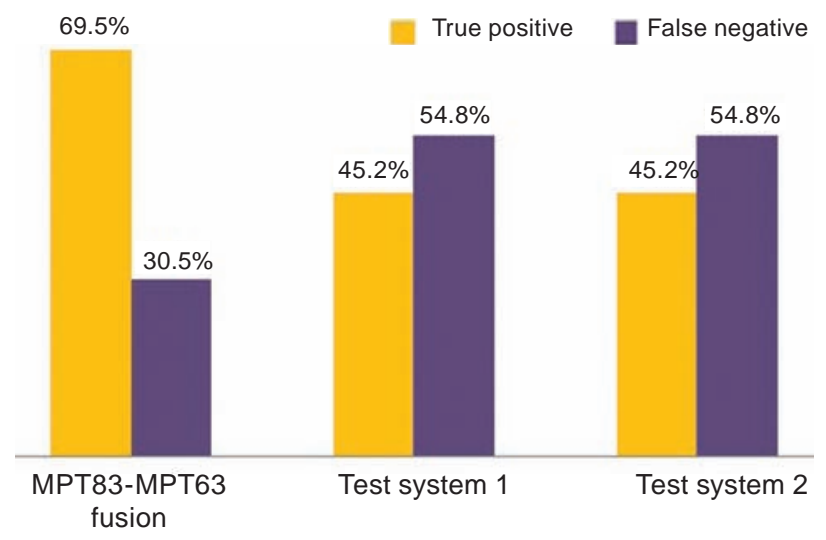

Fig. 2. Sensitivity of serological test systems ("IB-Chem Anti-Mycobacterium tuberculosis", \#1 (Ukraine), \#2 (Russia)), \%. All results are statistically confirmed, $P<0.05$ compared to each controls (with test-system \#1 and with test-system \#2)

It should be noted that the specificity of test system \#1 and \#2 were also similar and were 92.5 and 90.2\% respectively (Fig. 1) as in a case with MPT83MPT63 based ELISA (95.5\%) was high and hopeful for clinic investigation.

Achieving $100 \%$ sensitivity and specificity rate in a laboratory is practically impossible. The rela- tionship between sensitivity and specificity is such that the improvement of one indicator is accompanied by the deterioration of another. Thus, there is no such diagnostic kit that would guarantee absolute sensitivity and specificity in carrying out screening studies of the population.

Also, this study has shown the various hematological abnormalities which occurred in 50 patients with pulmonary TB. The sera biochemical values are shown in Table 1. Most biochemical blood parameters were at normal level for those sera, which were investigated in all three test systems or were not detected by any one. No changes were found in the level of creatinine in the blood in all groups of patients.

It is worth noting that the patients in which the diagnosis TB was not confirmed by any test systems (\#1, \#2 or MPT83-MPT63) higher level of glucose in the blood were observed both in males and females (5.90 \pm 0.75 and $5.80 \pm 0.05 \mu$ mole/l): in these patients glucose levels were higher than those who were recognized with \#1, \#2 $(5.1 \pm 0.1 \mu \mathrm{mole} / \mathrm{l})$ or MPT83-MPT63 ELISA kits (5.00 $\pm 0.05 \mu$ mole/l). Also, it level was increased than in non-infected healthy patients, but no diabetes in any TB patients were not confirmed.

Ta ble 1. The hematological and biochemical parameters of patients with pulmonary TB which recognized by test system \#1 (Ukraine) or \#2 (Russia), "IB-Chem Anti-Mycobacterium tuberculosis", by no one of testsystems and healthy controls

\begin{tabular}{|c|c|c|c|c|c|c|c|c|}
\hline \multirow[t]{2}{*}{ Parameters } & \multicolumn{2}{|c|}{$\begin{array}{c}\text { Test system \#1 } \\
\text { (Ukraine) and test } \\
\text { system \#2 (Russia) }\end{array}$} & \multicolumn{2}{|c|}{$\begin{array}{l}\text { "IB-Chem Anti- } \\
\text { Mycobacterium } \\
\text { tuberculosis" }\end{array}$} & \multicolumn{2}{|c|}{$\begin{array}{c}\text { Indicators of false } \\
\text { negative group } \\
\text { of patients }\end{array}$} & \multicolumn{2}{|c|}{ Reference value } \\
\hline & male & female & male & female & male & female & male & female \\
\hline ALT, U/l & 16.9 & 13.4 & 16.1 & 12.5 & 11.1 & 9.3 & Till 45 & Till 34 \\
\hline AST, U/l & 44.0 & 20.5 & 36.4 & 14.8 & 21.0 & 23.2 & Till 41 & Till 31 \\
\hline Creatinine, $\mu$ mole/l & 96.1 & 80.2 & 100.7 & 74.3 & 92.2 & 83.9 & $62-115$ & $53-97$ \\
\hline Total protein, g/l & 80.2 & 75.7 & 80.7 & 74.8 & 74.5 & $66,6^{*, \#}$ & $76-80$ & $79-83$ \\
\hline Glucose, $\mu$ mole/l & 5.0 & 5.2 & 5.0 & 5.0 & $5.9^{*, \#}$ & $5.8^{*, \#}$ & 3.3-5.5 & $3.3-5.5$ \\
\hline Leucocytes, $\times 10^{9} / 1$ & 6.1 & 5.7 & 6.6 & 7.1 & 8.4 & 6.6 & $4.2-9$ & $4-10.4$ \\
\hline Lymphocytes, \% & 26.0 & 32.8 & 28.8 & 33.0 & 25.3 & 29.8 & $18-40$ & $18-40$ \\
\hline Monocytes, \% & 4.4 & 7.0 & 5.4 & 6.5 & 7.1 & $10.6^{*, \#}$ & $2-8$ & $2-8$ \\
\hline Granulocytes, \% & 62.4 & 59.9 & 62.0 & 59.6 & 65.9 & 54.7 & $47-72$ & $47-72$ \\
\hline ESR, mm/h & $19.0^{\#}$ & 8.0 & $15.0^{\#}$ & 6.0 & 3.0 & 6.0 & $2-10$ & 3-15 \\
\hline
\end{tabular}

The difference between the group of men and women is not statistically confirmed: ALT (alanine aminotransferase) $P>0.5$; AST (aspartate aminotransferase) $P>0.5$; Creatinine $P>0.1$; Total protein $P>0.25$; Glucose $P>0.25$; Leucocytes $P>0.5$; Lymphocytes $P>0.5$; Monocytes $P>0.25$; Granulocytes $P>0.5$; ESR (erythrocyte sedimentation rate) $P>0.5$. $* P<0.05$ in compare with test system \#1, \#2 and MPT83-MPT63 based; ${ }^{\#} P<0.05$ in compare with reference values 
Our study noted raised erythrocyte sedimentation rate (ESR) in 1,5-2 times in male TB patients recognized by MPT83-MPT63 $(15 \pm 3 \mathrm{~mm} / \mathrm{h})$ and ELISA kit \#1 or \#2 (19 $\pm 2 \mathrm{~mm} / \mathrm{h})$ in compare with false negative recognized patient $(3 \pm 1 \mathrm{~mm} / \mathrm{h})$ or ESR in males $<10 \mathrm{~mm} / \mathrm{h}$ at normal. These values for women did not differ among groups.

Total leukocytes count was found within normal range in our study coinciding various studies $[18,21]$. There was no dramatic difference in the percentage of lymphocytes and neutrophils in groups of patients which were recognized by both comercial test-systems, MPT83-MPT63 based test-system or were incorrectly recognized. Moreovers, percentage of monocytes from total leucocytes was higher in false negative recognized patient group, especially in women $(10.60 \pm 0.45 \%)$, the figure exceeded the threshold. Monocytosis often occurs during chronic inflammation, including TB.

Thus, in the present study it was found that tuberculosis patients with high glucose, low protein level and increase of monocytes count with simultaneous reduction of lymphocytes adversely affects on ELISA recognition results with appear false-negative sera samples. Some of these indicators do not refer to purely immunological, but all of these changes are the result of prolonged inflammatory processes or similar pathologies etc.

According to our investigation we can state the importance of a comprehensive tuberculosis screening test, a level of specific antibodies and a biochemical blood test, which is an auxiliary test to determine the severity of the disease.

Resistance to TB drugs is a formidable obstacle to effective TB care and prevention globally. Multidrug-resistant tuberculosis (MDR-TB) is an increasing global problem, with most cases arising from a mixture of physician error and patient noncompliance during treatment of susceptible TB [21]. One of the tasks of our work was the comparison of patients infected with mycobacteria with varying resistance to drugs for recognition by serological tests. We did not find the correlation difference between the recognition of patients with MDR-TB or extensively drug-resistant tuberculosis (XDR-TB) among comercial and MPT83-MPT63 test-systems. However, it was interesting to note that commercial tests could correctly detect antibodies to the pathogen in only 1 of 10 patients infected rifampicin resistant strains, while the effectiveness of MPT83-MPT63 based "IB-Chem Anti-Mycobacterium tuberculosis" was 50\% (5 of 10 patients) (Table 2). So, above-mentioned results is in favor of the use "IB-Chem AntiMycobacterium tuberculosis" (Fig. 3): the proposed test-system is characterized by not worse indicators of reliability of serological tests, and in some cases exceeds them.

In this study, a novel ELISA kit "IB-Chem Anti-Mycobacterium tuberculosis" was developed and the related parameters were optimized and evaluated for enhanced reactivity, specificity and sensitivity in a pool of confirmed TB patients. Mycobacterial genes which were fused previously to obtain MPT83-MPT63 chimeric antigen from E. coli Rosetta DE3 expression system. This high immunogenic substance was characterized and was exploited for improved serodiagnostic test against pulmonary TB cases with greater sensitivity and little bit higher specificity as compared to other commercially available tests.

We hope that parallel detection of TB-specific antibodies and biomarkers of inflammation (both biochemical and hematological) will give a wider picture of the course of the infection to determine the

Ta b le 2. Comparison of serodiagnostics recognition of TB patients with various drug-resistant status

\begin{tabular}{|c|c|c|c|c|c|c|}
\hline \multirow[t]{2}{*}{ Diagnosis } & \multicolumn{2}{|c|}{$\begin{array}{l}\text { Test system \#1 (Ukraine) } \\
\text { and test system \#2 (Russia) }\end{array}$} & \multicolumn{2}{|c|}{$\begin{array}{l}\text { "IB-Chem Anti- } \\
\text { Mycobacterium } \\
\text { tuberculosis" }\end{array}$} & \multicolumn{2}{|c|}{ False negative recognized } \\
\hline & male & female & male & female & male & female \\
\hline MDR-TB & 3 & 19 & 9 & 15 & 3 & 2 \\
\hline XDR-TB & 3 & 1 & 3 & 3 & 1 & 2 \\
\hline RifR-TB & 1 & 0 & 2 & 3 & 1 & 4 \\
\hline Total & \multicolumn{2}{|c|}{27} & \multicolumn{2}{|c|}{35} & \multicolumn{2}{|c|}{13} \\
\hline
\end{tabular}

MDR-TB - multi-drug-resistant tuberculosis, XDR-TB - extensively drug-resistant tuberculosis, RifR-TB rifampicin-resistant tuberculosis 


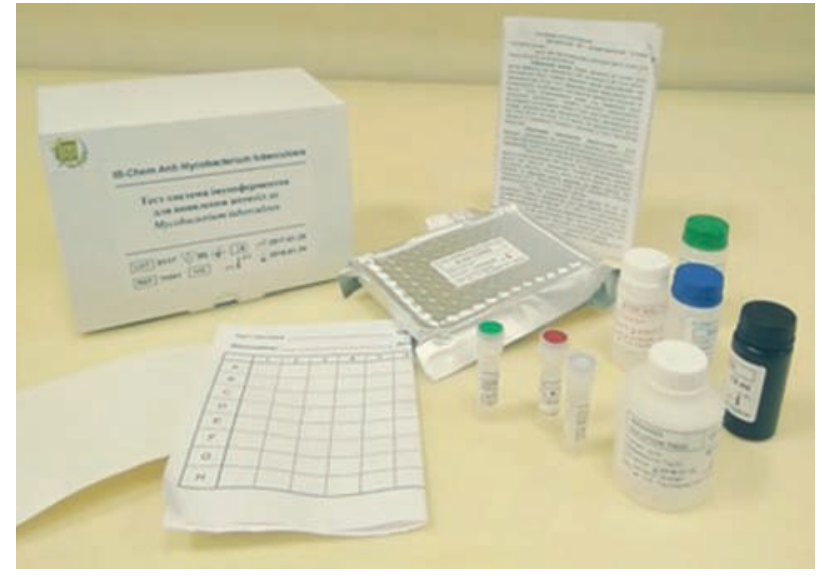

Fig. 3. Industrial sample of "IB-Chem Anti-Mycobacterium tuberculosis" test system for diagnostics of human pulmonary TB: set of components and instruction

status of the patient. However, using only a MPT83MPT63 based test-system without preliminary diagnosis of blood parameters proved itself. Thus, the study suggests possible application of the "IB-Chem Anti-Mycobacterium tuberculosis" ELISA to routine mass screening and early-stage diagnosis of TB.

Competing interests. The authors declare that they have no competing interests.

Acknowledgements. We are grateful to our colleages from RAMINTEK Ltd. Innovation-Production Company and State Institution "National Institute of Phthisiology and Pulmonology named after F. G. Yanovsky National Academy of Medical Sciences of Ukraine" for healthy, TB and non-tuberculous lung diseases patients sera samples providing. Particular thanks to physicians for the detailed analysis of patients blood biochemical parameters and haemograms.

Funding. This work was supported by the State order for scientific and technical products (№0115U001969) which was carried out in 20152016.

\section{СПЕЦИФІЧНІСТЬ ТА ЧУТЛИВІСТЬ \\ НОВОГО ТЕСТУ ДЛЯ \\ СЕРОЛОГІЧНОЇ ДІАГНОСТИКИ \\ ТУБЕРКУЛЬОЗУ НА ОСНОВІ \\ ЗЛИТОГО АНТИГЕНУ МРТ83- МPT63}

А. А. Сіромолот ${ }^{1,2 凶}$, Т. О. Чудіна ${ }^{2}$,

I. С. Данілова , О. М. Рекалова

Д. В. Колибо ${ }^{1,2}$, С. В. Комісаренко ${ }^{2}$

${ }^{1}$ ННЦ «Інститут біології та медицини»,

Київський національний університет імені Тараса Шевченка, Україна;

${ }^{2}$ Інститут біохімії ім. О. В. Палладіна НАН України, Київ;

${ }^{3} \mathrm{HНЦ} \mathrm{«Інститут} \mathrm{експериментальної} \mathrm{та} \mathrm{клінічної}$ ветеринарної медицини», Харків, Україна;

${ }^{4} Д У$ «Національний інститут фтизіатрії і пульмонології ім. Ф. Г. Яновського НАМН України», Київ; 凶e-mail: saa0205@ukr.net

Метою цієї роботи було провести порівняльну характеристику експериментальної тест-системи з використанням злитого протеїну МРТ83-МРТ63 з референсними комерційними діагностикумами та дослідити основні оцінювальні характеристики імуноензимних тестів, таких як специфічність та чутливість. Крім того, ми намагалися дослідити кореляційну залежність біохімічних та імунологічних показників зразків крові пацієнтів із ТБ та тест-системами, які правильно діагностували захворювання у цих пацієнтів. Показано, що запропонована нами експериментальна тест-система не поступається існуючим діагностичним серологічним тестам щодо критеріїв вірогідності, інформативності та основним вимогам використання подібних імуноензимних тестів. Розроблено інструкцію щодо тестування зразків сироваток та показання до використання серологічних методів діагностики, що пропонуються.

К л юч о в і слов в: діагностика туберкульозу, рекомбінантний протеїн, ELISA. 
СПЕЦИФИЧНОСТЬ И

ЧУВСТВИТЕЛЬНОСТЬ НОВОГО

ТЕСТА ДЛЯ СЕРОЛОГИЧЕСКОЙ

ДИАГНОСТИКИ ТУБЕРКУЛЕЗА НА

ОСНОВЕ МРТ83-МРТ63 СЛИТОГО АНТИГЕНА

А. А. Сиромолот ${ }^{1,2 \bowtie}$, Т. А. Чудина ${ }^{2}$,

И. С. Данилова ${ }^{3}$, Е. М. Рекалова ${ }^{4}$,

Д. В. Колибо ${ }^{1,2}$, С. В. Комисаренко ${ }^{2}$

${ }^{1}$ УНЦ «Институт биологии и медицины», Киевский национальный университет имени Тараса Шевченко, Украина;

${ }^{2}$ Институт биохимии им. А. В. Палладина НАН Украины, Киев;

${ }^{3}$ ННЦ «Институт экспериментальной и клинической ветеринарной медицины», Харьков, Украина;

${ }^{4} Г У$ «Национальный институт фтизиатрии и пульмонологии им. Ф. Г. Яновского

НАМН Украины», Киев;

凶e-mail: saa0205@ukr.net

Целью работы было проведение сравнительной характеристики экспериментальной тест-системы с использованием слитого протеина МРТ83-МРТ63 с референсными коммерческими диагностикумами и исследование базовых характеристик иммуноэнзимных тестов, таких как специфичность, и чувствительность. Кроме того, мы попытались исследовать корреляционную зависимость биохимических и иммунологических параметров образцов крови пациентов с ТБ и тест-системами, которые правильно диагностировали болезнь у этих пациентов. Было показано, что предлагаемая нами экспериментальная тест-система не уступает существующим диагностическим серологическим тестам по критериям достоверности, информативности и основным требованиям использования подобных иммуноэнзимных тестов. Разработаны инструкция по тестированию образцов сывороток и показания к использованию предлагаемых серологических методов диагностики.

К л ю ч е в ы е с л о в а: диагностика туберкулеза, рекомбинантный протеин, ELISA.

\section{References}

1. World Health Organization. Global tuberculosis report 2017. Available at: http://www.who.int/ tb/publications/global_report/en/_ (acsessed, February, 2018).

2. Abebe F, Holm-Hansen C, Wiker HG, Bjune G. Progress in serodiagnosis of Mycobacterium tuberculosis infection. Scand J Immunol. 2007; 66(2-3): 176-191.

3. Shin AR, Shin SJ, Lee KS, Eom SH, Lee SS, Lee BS, Lee JS, Cho SN, Kim HJ. Improved sensitivity of diagnosis of tuberculosis in patients in Korea via a cocktail enzymelinked immunosorbent assay containing the abundantly expressed antigens of the $\mathrm{K}$ strain of Mycobacterium tuberculosis. Clin Vaccine Immunol. 2008; 15(12): 1788-1795.

4. Tiwari D, Tiwari RP, Chandra R, Bisen PS, Haque S. Efficient ELISA for diagnosis of active tuberculosis employing a cocktail of secretory proteins of Mycobacterium tuberculosis. Folia Biol (Praha). 2014; 60(1): 10-20.

5. Siromolot AA, Oliinyk OS, Kolibo DV, Gerilovych AP. Improvement and optimization of antigenic composition for serodiagnosis of tuberculosis. J Veter Med Biotechnol Biosafety. 2016; 2(4): 11-15.

6. Redchuk TA, Korotkevich NV, Kaberniuk AA, Oliinyk OS, Labyntsev AIu, Romaniuk SI, Kolibo DV, Busol VA, Komisarenko SV. Statistical analysis of the distribution of the antibody levels to Mycobacterium bovis antigenes for bovine tuberculosis diagnostics. Cytol Genet. 2010; 44(5): 280-285.

7. Matsegora NA, Golubenko MYu, Lekan OYa, Omelian LP. Changes in haemogram in pulmonary TB patients during positive clinical and radiology improvement. J Educ Health Sport. 2017; 7(1): 317-322.

8. Rohini K, Bhat S, Srikumar PS, Mahesh Kumar A. Serum PCT and its Relation to Body Weight Gain in Pulmonary Tuberculosis. Indian J Clin Biochem. 2015; 30(3): 329-333.

9. Yusra Akram, Zahed Mahmood, Muhammad Riaz, Irum Javed, Muhammad Shahid, Tahira Batool, Syed Muhammad Ali Shah, Naveed Munirand, Imtiaz Mahmood Tahir. Biochemical profiling of tuberculosis patients co-infected with hepatitis C virus. Eur J Inflamm. 2016; 15(1): 42-45. 
10. Hungund BR, Sangolli SS, Banhur HB, Malur PR, Pilli GS, Chavan RY, Dafale SR, Joshi AV. Blood and bone marrow findings in tuberculosis in adults - A cross sectional study. Al Ameen J Med Sci. 2012; 5(4): 362-366.

11. Schrijver RS, Kramps JA. Critical factors affecting the diagnostic reliability of enzymelinked immunosorbent assay formats. Rev Sci Tech. 1998; 17(2): 550-561.

12. Wielkopolska A, Gut W, Binduga-Gajewska I, Jarzabek Z. Evaluation of the usefulness of the ELISA method for detection of enterovirus antibodies in serum samples of patients with myocarditis. Med Sci Monit. 2002; 8(1): MT10MT14.

13. Iqbal S, Ahmed U, Khan MA. Haematological parameters altered in tuberculosis. Pak J Physiol. 2015; 11(1): 13-16.

14. Parasappa Joteppa Yaranal, Toolhally Umashankar, Sadula Govindareddy Harish. Hematological Profile in Pulmonary Tuberculosis. Int J Health Rehabil Sci. 2013; 2(1): 50-55.

15. Oliva VM, Cezário GAG, Cocato RA, Marcondes-Machado J. Pulmonary tuberculosis: hematology, serum biochemistry and the relation with the disease duration. $J$ Venom Anim Toxins Incl Trop Dis. 2008; 14(1): 71-81.

16. Hager Ali Shareef, Nizar Ramadan M. Amin. Abnormalities of hematological parameters in newly diagnosed pulmonary tuberculosis patients in Kirkuk city. J Babylon Univ. Pure Appl Sci. 2012; 20(5): 1-7.
17. Patience A, Akpotuzor JO, Akwiwu Ephoria C. Some Haematological Parameters of Tuberculosis (TB) Infected Africans: The Nigerian Perspective. J Nat Sci Res. 2012; 2(1): 50-57.

18. Kulkarni NS, Jaju S. Study of Hematological and Biochemical Parameters in Pulmonary Tuberculosis. Int J Sci Res. 2017; 6(9): 1534-1536.

19. Morozov VN, Nikolaev AA, Shlyapnikov YM, Mikheev AY, Shlyapnikova EA, Bagdasaryan TR, Burmistrova IA, Smirnova TG, Andrievskaya IY, Larionova EE, Nikitina IY, Lyadova IV. Non-invasive approach to diagnosis of pulmonary tuberculosis using microdroplets collected from exhaled air. J Breath Res. 2018; 12(3): 036010.

20. World Health Organization. Commercial serodiagnostic tests for diagnosis of tuberculosis: policy statement. 2011, WHO Library Cataloguing-in-Publication Data. Available at http:. apps.who.int.iris.bitstre am.10665.44652.1.9789241502054_eng.pdf.

21. Zumla A, Chakaya J, Centis R, D'Ambrosio L, Mwaba P, Bates M, Kapata N, Nyirenda T, Chanda D, Mfinanga S, Hoelscher M, Maeurer M, Migliori GB. Tuberculosis treatment and management - an update on treatment regimens, trials, new drugs, and adjunct therapies. Lancet Respir Med. 2015; 3(3): 220-234.

Received 25.06.2018 